\title{
PENERAPAN REMEDIASI PADA SISTEM BUDIDAYA UDANG DI TAMBAK TANAH SULFAT MASAM (Studi Kasus di Kabupaten Berau, Kalimantan Timur)
}

\author{
Tri Heru Prihadi\# dan Brata Pantjara \\ Balai Riset Perikanan Budidaya Air Tawar dan Penyuluhan Perikanan \\ Jl. Sempur No. 1, Bogor 16129 \\ (Naskah diterima: 29 Agustus 2018; Revisi final: 17 Juni 2019; Disetujui publikasi: 17 Juni 2019)
}

\begin{abstract}
ABSTRAK
Remediasi tanah sulfat masam untuk tambak dapat meningkatkan produktivitas tanah yang lebih baik untuk budidaya udang sistem monokultur dan polikultur. Penelitian dilakukan bertujuan untuk mengetahui pengaruh remediasi tanah pada budidaya udang windu di tambak tanah sulfat masam. Penelitian dilakukan pada tambak milik masyarakat di Pulau Tempurung, Desa Kasai Kecamatan Pulau Derawan Kabupaten Berau Provinsi Kalimantan Timur. Karakterisasi tanah untuk mengetahui rona awal tambak tanah sulfat masam dilakukan sebelum budidaya. Prosedur perbaikan tambak tanah sulfat masam diadopsi dari hasil penelitian Balai Riset Perikanan Budidaya Air Payau dan Penyuluhan Perikanan (BRPBAPPP). Remediasi tanah dilakukan dengan tahapan pengolahan tanah, pengeringan dasar tambak, perendaman, dan pembilasan; dan dilanjutkan dengan pengapuran dan pemupukan. Pengapuran tambak menggunakan dolomit dengan dosis 1,0 ton per ha. Hasil penelitian menunjukkan bahwa tambak yang diremediasi menghasilkan udang windu sebanyak 357,15 kg/ha dan tanpa remediasi sebesar $100 \mathrm{~kg} / \mathrm{ha}$. Tambak yang diremediasi pada sistem polikultur menghasilkan udang windu 100,9 kg/ha dan ikan bandeng $330 \mathrm{~kg} / \mathrm{ha}$. Penerapan teknologi remediasi dasar tanah pada budidaya udang windu sistem monokultur berdasarkan analisis ekonomi sederhana memberi keuntungan sebesar Rp26.828.500,00/ha/siklus dan BC rasio 4,68. Polikultur udang windu dan bandeng menghasilkan keuntungan sebesar Rp8.800.000,00/ha/siklus dan BC rasio 2,47.
\end{abstract}

\section{KATA KUNCl: $\quad$ tanah sulfat masam; remediasi; tambak; udang windu; ikan bandeng \\ ABSTRACT: Remediation application of acid sulphate soil pond of shrimp culture system: a case study in Berau, East Kalimantan. By: Tri Heru Prihadi and Brata Pantjara}

Remediation of acid sulfate soil pond can increase the productivity of the soil used for shrimp farming with monoculture and polyculture systems. This study was conducted to determine the post effects of soil remediation on tiger shrimp cultured in acid sulfate soil pond. The study was conducted in one of the farms owned by a fish farmer in Tempurung Island, Kasai Village, Derawan District, Berau Regency, East Kalimantan Province. The characteristics of the soil were determined to serve as the baseline information before cultivation. The pond remediation followed the procedures set by the Research Institute for Brackishwater Aquaculture and Fisheries Extension, Maros. The soil reclamation was carried out following the subsequent stages: soil plowing, pond bottom drying, inundation, and flushing; followed by liming and fertilization. Ponds liming used a dolomite dose of 1 ton/ha. The results showed that the remediated acid sulfate soil ponds could produce tiger shrimp up to $357.15 \mathrm{~kg} / \mathrm{ha}$ while non-remediated ponds only produced up to of $100 \mathrm{~kg} / \mathrm{ha}$. The remediated brackish fish pond used for polyculture system could producetiger shrimp up to $100.9 \mathrm{~kg} /$ ha and milkfish up to $330 \mathrm{~kg} / \mathrm{ha}$. The application of soil remediation on ponds of tiger shrimp monoculture systems yielded a profit of $\mathrm{Rp} 26,828,500.00 / \mathrm{Ha} /$ cycle and $\mathrm{BC}$ ratio of 4.68 . For polyculture of tiger shrimp and milkfish, the profit was $\mathrm{Rp} 8,800,000.00 / \mathrm{Ha} /$ cycle and $\mathrm{BC}$ ratio of 2.47 .

\section{KEYWORDS: acid sulfate soil; remediation; brackishwater pond; tiger shrimp; milkfish}

\footnotetext{
\# Korespondensi: Balai Riset Perikanan Budidaya Air Tawar dan Penyuluhan Perikanan. Jl. Sempur No. 1, Bogor 16129, Indonesia

Tel.: + 622518313200

E-mail: triheru_p@yahoo.com
} 


\section{PENDAHULUAN}

Potensi tambak di Kabupaten Berau, Kalimantan Timur mencapai 3.710,76 ha (Ratnawati \& Asaad, 2012). Pengembangan tambak di Kabupaten Berau memerlukan perencanaan, pengelolaan, dan pemanfaatan yang tepat sesuai daya dukung lingkungan tambak terutama kualitas tanah tambak dan penerapan teknologi yang dikembangkan. Potensi tambak di Kabupaten Berau berdasarkan analisis kualitas lahan atau daya dukung kawasan pertambakan menunjukkan nilai kualitas lahan yang layak dan bisa digunakan untuk tambak sebesar $65,30 \%$

Di Kabupaten Berau, pada umumnya tambak yang dibangun tergolong marginal (tanah sulfat masam dan gambut) atau asosiasi dari kedua jenis tanah tersebut. Kawasan tambaknya terjangkau air pasang surut dan kondisi tanahnya tergenang (anaerob). Tambak terlihat kurang terawat dan terkesan terlantar karena tambaknya tidak berproduksi sehingga sering dianggap tambak marginal yang masih memerlukan banyak perbaikan untuk meningkatkan produktivitas tambaknya (Pantjara, 2004). Namun karena kebutuhan lahan untuk akuakultur semakin meningkat, maka pemanfaatan lahan semacam ini merupakan lahan alternatif yang bisa dikembangkan dan dapat diberdayakan.

Tanah sulfat masam (TSM) terbentuk karena kandungan sulfat, besi, dan bahan organik yang cukup tinggi dan kondisi tanah tambak yang anaerob. Permasalahan yang dijumpai pada tanah sulfat masam adalah produktivitas tanahnya yang rendah terutama kemasamannya yang disebabkan oleh kandungan pirit, $\mathrm{Fe}^{2+}, \mathrm{Al}^{3+}$, dan $\mathrm{SO}_{4}{ }^{2-}$, serta kandungan bahan organik yang tinggi (Breemen, 1993; Mensvoort \& Dent, 1998).

Dilaporkan Pantjara (2004) bahwa kondisi tanah yang masam dan menurunnya kualitas lingkungan dapat menyebabkan kegagalan dalam budidaya udang, karena udang tidak dapat tumbuh optimal, rentan terhadap penyakit, dan mortalitas tinggi. Permasalahan di tambak muncul setelah pemeliharaan berlangsung $>$ 30 hari. Hal ini karena terlarutnya senyawa toksin dalam air yang menurunkan kualitas air (Pantjara, 2004). Pada kondisi lingkungan yang jelek memudahkan berkembangnya patogen, sehingga dalam pemanfaatan tanah masam untuk budidaya tambak diperlukan strategi pengelolaan yang optimal dan alternatif teknologi budidaya yang tepat.

Peningkatan produktivitas tambak TSM diharapkan dapat mempertahankan kualitas air tetap baik dan udang dapat tumbuh dengan optimal. Upaya tersebut antara lain dengan mengurangi tingkat kelarutan senyawa toksin dasar tambak melalui remediasi tanah yang meliputi pengolahan tanah dasar, pengeringan, pembilasan, dan dilanjutkan dengan pengapuran. Remediasi dasar tambak dan diikuti dengan perbaikan pematang dapat meningkatkan produksi udang dibandingkan tambak yang hanya dengan reklamasi saja. Remediasi tanah dasar dan perbaikan pematang dengan pelapisan plastik di tambak TSM dapat meningkatkan kualitas air tambak yang lebih baik (Pantjara et al., 2007).

Produktivitas tambak TSM ditentukan oleh unsur yang dikandung dalam TSM. Remediasi dasar tambak TSM menghasilkan udang windu sebesar $120-250 \mathrm{~kg} /$ ha dan yang tidak diremediasi sebanyak $50-143 \mathrm{~kg} / \mathrm{ha}$ selama 70 hari (Pantjara et al., 2010). Dengan demikian tambak TSM dapat diberdayakan bila dilakukan persiapan dan pengelolaan tambak yang tepat dan komoditas yang dikembangkan dapat tumbuh dan hidup sesuai dengan kondisi lingkungan tambak TSM. Penelitian ini bertujuan untuk mengetahui pengaruh remediasi tanah untuk budidaya udang windu di tambak TSM Kabupaten Berau, Kalimantan Timur.

\section{BAHAN DAN METODE}

Penelitian dilakukan di tambak milik masyarakat di Pulau Tempurung, Desa Kasai Kecamatan Pulau Derawan Kabupaten Berau Provinsi Kalimantan Timur. Sebelum budidaya telah dilakukan karakterisasi tanah yang diperlukan untuk mengetahui rona awal tambak TSM sebelum dilakukan budidaya. Perbaikan tambak TSM mengacu pada Pantjara et al. (2007). Kondisi tambak yang digunakan merupakan tambak hamparan yang mempunyai luasan beragam dengan bentuk yang bervariasi sehingga menjadi pertimbangan pada saat penelitian. Untuk budidaya udang windu sistem monokultur menggunakan tambak ukuran $1.400 \mathrm{~m}^{2}$ $(0,14 \mathrm{ha}) ;$ sedangkan tambak untuk polikultur udang dan bandeng mempunyai luasan $25.000 \mathrm{~m}^{2}$ (2,5 ha).

Persiapan tambak sebelum budidaya dilakukan meliputi perbaikan pematang, tandon, pintu air, jembatan tambak dan saluran pemasukan, dan pembuangan air. Remediasi tanah dasar meliputi remediasi tanah dasar, pengapuran, dan pemupukan. Sementara itu, remediasi tanah yang dilakukan meliputi pengolahan tanah, pengeringan dasar tambak, perendaman, dan pembilasan. Pemberantasan hama dengan menggunakan saponin dosis $50 \mathrm{mg} / \mathrm{L}$. Pengapuran tambak menggunakan dolomit dosis 1,0 ton/ha.

Teknologi budidaya udang windu yang dikembangkan adalah (A). Budidaya udang windu ekstensif plus dan (B). Polikultur udang windu dan bandeng. Padat penebaran tokolan udang windu adalah 40.000 ekor/ha pada perlakuan A. Sedangkan B, 
tokolan udang windu 20.000 ekor/ha dan gelondongan bandeng 1.000 ekor/ha. Pengamatan pertumbuhan udang dilakukan setiap dua minggu. Pemberian pakan (pelet) dilakukan 30 hari setelah udang ditebar (diperkirakan pakan alami sudah tidak mencukupi). Dosis pakan adalah $5 \% 2 \%$ bobot badan/hari yang diberikan dua kali sehari. Pengapuran susulan dilakukan apabila terjadi penurunan $\mathrm{pH}$ air pada saat berlangsungnya budidaya. Dosis kapur susulan adalah 2-6 $\mathrm{mg} / \mathrm{L}$ atau tergantung kondisi $\mathrm{pH}$ air tambak. Pemeliharaan dilakukan selama 90 hari. Analisis kualitas tanah tambak meliputi: $\mathrm{pH}_{\mathrm{F}}$ dan $\mathrm{pH}_{\mathrm{Fox}}$, dan potensial redoks, bahan organik total, N-total, pirit, TPA, TAA, TSA, SPOS, $\mathrm{P}_{2} \mathrm{O}_{5}$, dan tekstur tanah menggunakan Principal Componen Analysis (PCA). Sementara itu, analisis kualitas air tambak meliputi warna air, suhu, salinitas, pH, oksigen terlarut, padatan tersuspensi total, bahan organik total, fosfat. Prosedur analisis tanah mengikuti petunjuk Ahern et al. (1998), sedangkan analisis air mengikuti petunjuk APHA (1998). Pada akhir penelitian dilakukan analisis ekonomi.

\section{HASIL DAN BAHASAN}

\section{Kondisi Umum}

Kondisi iklim di Kabupaten Berau dipengaruhi oleh kondisi iklim di Samudera Pasifik (musim barat) dan musim timur. Curah hujan di Kabupaten Berau tergolong sedang 2.260,9 mm/tahun $(2.000-2.500 \mathrm{~mm} /$ tahun). Kondisi tersebut baik karena dengan kondisi curah hujan tinggi dapat menyulitkan pengeringan tambak secara sempurna, bahkan sebagian dasar tambak tidak pernah kering. Selain itu, juga menyebabkan sungai mempunyai salinitas yang rendah.

Perairan laut (oseanografi) di sekitar lokasi tambak terutama sungainya dipengaruhi oleh pergerakan arus musiman dan arus lintas Indonesia dari Samudera Pasifik menuju Samudera Hindia yang melewati Selat Makasar. Dilihat dari pola gerakan muka lautnya, maka pasang surut di Kabupaten Berau adalah pasang surut tipe harian berganda (semidiurnal tide), karena setiap hari terjadi dua kali pasang dan dua kali surut. Dilaporkan Poernomo (1992), rataan amplitudo pasang surut antara 110-210 cm masih layak bagi pengelolaan pertambakan udang di kawasan intertidal. Data hasil pengukuran pasang surut di Kabupaten Berau menunjukkan bahwa pasang surutnya mencapai 285 $\mathrm{cm}$.

Jenis tanah tambak tergolong TSM dan sebagian bergambut. Dilaporkan pembudidaya tambak (Komunikasi pribadi, 2013) di sekitar lokasi penelitian, tambaknya mempunyai produksi yang rendah, sekitar 100 kg/ha/tahun. Produktivitas tambak yang rendah ini disebabkan kemasaman, adanya kelarutan besi dan sulfat yang tinggi pada tanah dan air sehingga berakibat fatal bagi udang windu (Gambar 1).

\section{Kualitas Tanah}

Tambak TSM dicirikan dengan kemasaman tinggi (pH rendah), kapasitas tukar kation rendah, kejenuhan basa dan C-organik rendah, kandungan besi dan aluminium tinggi, fiksasi $\mathrm{P}$ tinggi, kandungan besi dan mangan tinggi, peka terhadap erosi, dan kurang hara tersedia (Evangelou \& Zhang, 1995; Pantjara, 2004; 2008). Remediasi tanah dapat menurunkan konsentrasi oksida besi (kurangnya ketersediaan $\mathrm{Fe}^{2+}$ yang tereduksi) dan ketersediaan bahan organik. Pengolahan tanah dan pengerigan dapat mengoksidasikan senyawa toksin dan senyawa tersebut dapat melarutkan $\mathrm{Fe}^{2+}, \mathrm{Al}^{3+}, \mathrm{SO}_{4}{ }^{2-}$, dan asam organik. Untuk itu, dalam proses pembuangan harus diupayakan tidak menjadikan beban limbah beracun pada tambak sekitarnya atau perairan sekitarnya. Hal yang sama juga dilaporkan Cook et al. (2000) bahwa pembuangan air dari tambak TSM dapat memberikan dampak kemasaman dan menambah unsur toksin di perairan.

Elevasi dasar tambak berada di posisi rataan surut terendah menyebabkan tingkat pencucian hara tinggi sehingga yang tertinggal dalam tanah tersebut pada kompleks adsorpsi liat dan humus adalah ion $\mathrm{H}^{+}$, $\mathrm{Fe}^{2+, 3+}$, dan $\mathrm{Al}^{3+}$, sehingga tanah menjadi masam. Hasil analisis kualitas tanah tambak yang digunakan untuk penelitian disajikan pada Tabel 1.

Kemasaman tanah yang tinggi disebabkan $\mathrm{pH}_{\mathrm{Fox}}$ sangat rendah yaitu 0,71-1,51 walaupun $\mathrm{pH}_{\mathrm{F}}$ yang langsung diukur di lapangan mencapai kisaran5,976,92 . Selisih dari $\mathrm{pH}_{\mathrm{F}}-\mathrm{pHFOX}$ merupakan potensi kemasaman berdasarkan nilai pH cukup tinggi $(5,26$ 5,55); nilai potensial redoks mencapai kisaran -185 $\mathrm{mV}$ hingga $-29 \mathrm{mV}$, kondisi ini menunjukkan bahwa tanah sering tergenang air. $\mathrm{N}$ total rendah $(0,110 \%$ 0,160\%; mengindikasikan proses dekomposisi bahan organik berjalan sangat lambat, orto fosfat $\left(\mathrm{P}_{2} \mathrm{O}_{5}\right)$ rendah $(22,51-72,98 \mathrm{mg} / \mathrm{L})$, bahan organik $(5,27 \%$ $14,07 \%$, $\mathrm{Fe}^{2+}(6876-8893 \mathrm{mg} / \mathrm{L})$, pirit tergolong tinggi $(0,723 \% 2,580 \%$, dan tekstur lempung berpasir dengan komposisi seperti pada Tabel 1.

Hasil anal isis faktor dari 12 variable yaitu $\mathrm{pH}_{\mathrm{F}^{\prime}} \mathrm{pH}_{\mathrm{Fox}}$ potensial redoks, bahan organik, $\mathrm{N}, \mathrm{P}_{2} \mathrm{O}_{5}, \mathrm{Fe}^{2+}$, pirit, TPA, TAA, TSA, dan SPOS terhadap kualitas tanah tambak TSM dengan nilai eigen (> 1), maka sebesar 83,80\%produktivitas tanah ditentukan atau dibentuk oleh tiga komponen, yaitu komponen-1 dengan nilai eigen 6,62; sebesar 55,17\%produktivitas tambak TSM ditentukan $\mathrm{pH}_{\mathrm{F}}(-0,898)$; potensial redoks $(0,743)$; 


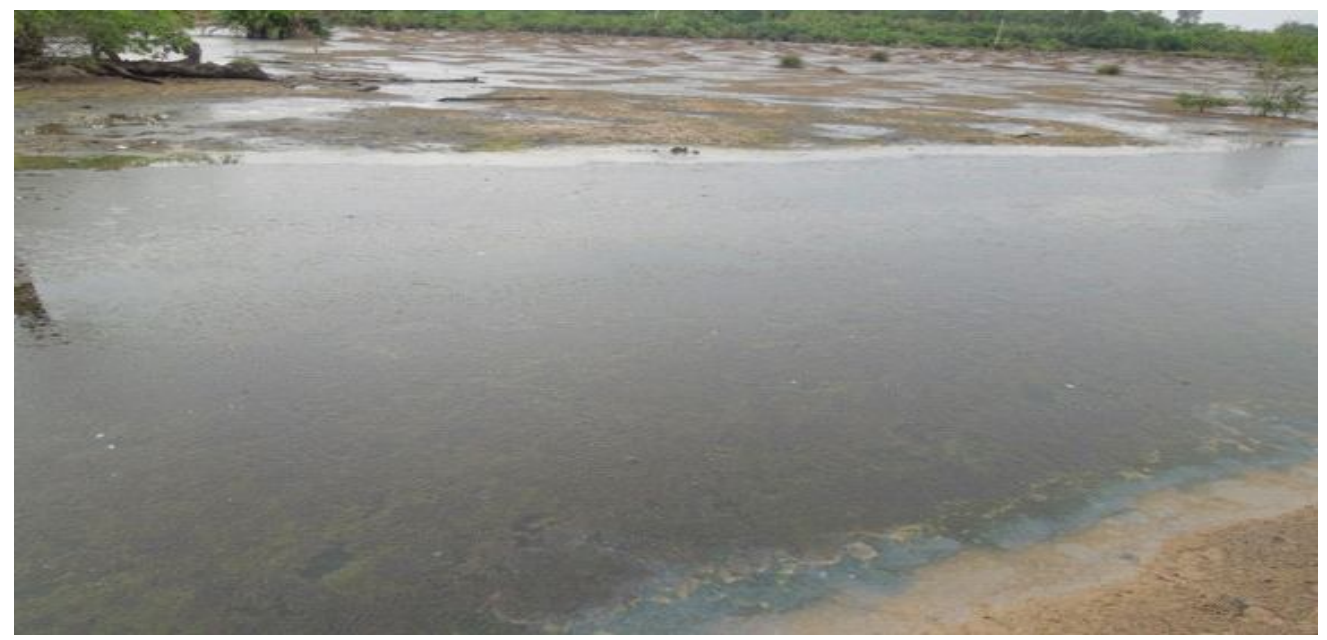

Gambar 1. Kondisi tanah tambak untuk budidaya air payau yang didominasi tanah sulfat masam (TSM).

Figure 1. The soil conditions for brackish water pond with apparent acid sulphate signs (TSM).

Tabel 1. Kisaran dan rata-rata kualitas tanah tambak TSM di Kabupaten Berau, Kalimantan Timur

Table 1. The range and average quality of TSM soil in Berau, West Kalimantan.

\begin{tabular}{lccc}
\hline \multicolumn{1}{c}{$\begin{array}{c}\text { Parameter } \\
\text { Parameters }\end{array}$} & $\begin{array}{c}\text { Satuan } \\
\text { Unit }\end{array}$ & $\begin{array}{c}\text { Kisaran } \\
\text { Range }\end{array}$ & $\begin{array}{c}\text { Rata-rata } \pm \text { Standar deviasi } \\
\text { Average } \pm \text { Standard deviation }\end{array}$ \\
\hline $\mathrm{pH}_{\mathrm{F}}$ & - & $5.97-6.92$ & $6.57 \pm 0.424$ \\
$\mathrm{pH}_{\text {Fox }}$ & - & $0.71-1.51$ & $1.145 \pm 0.3511$ \\
$\mathrm{pH}_{\mathrm{F}}-\mathrm{pH}_{\text {Fox }}$ & - & $5.26-5.55$ & $5.425 \pm 0.1239$ \\
Redoks (Redox) & $\mathrm{mV}$ & $-185)-(-29)$ & $-107.25 \pm 79.609$ \\
Bahan organik (Organic matter) & $\%$ & $5.27-14.07$ & $8.43 \pm 3.9475$ \\
$\mathrm{C}$-organik (C-organic) & $\%$ & $3.60-8.161$ & $4.893 \pm 2.29$ \\
$\mathrm{~N}$ total & $\%$ & $0.110-0.160$ & $0.139 \pm 0.0241$ \\
$\mathrm{P}_{2} \mathrm{O}_{5}$ & $\mathrm{mg} / \mathrm{L}$ & $22.51-72.98$ & $45.05 \pm 21.16$ \\
$\mathrm{Fe}{ }^{2+}$ & $\mathrm{mg} / \mathrm{L}$ & $6876-8893$ & $8,720 \pm 1,495$ \\
$\mathrm{TPA}$ & $\mathrm{mol} \mathrm{H} /$ ton & $162-578$ & $306.1 \pm 192.4$ \\
$\mathrm{TAA}$ & $\mathrm{mol} \mathrm{H} /$ ton & $\mathrm{ttd}$ & $\mathrm{ttd}$ \\
$\mathrm{TSA}$ & $\mathrm{mol} \mathrm{H} /$ ton & $162-578$ & $344.3 \pm 196.9$ \\
$\mathrm{SPOS}$ & $\%$ & $0.280-1.582$ & $1.025 \pm 0.4090$ \\
Pirit (Pyrite) & $\%$ & $0.723-2.580$ & $1.537 \pm 0.879$ \\
Tekstur (Texture) & $\%$ & & \\
$-\quad$ Pasir (Sand) & $\%$ & $48-62$ & $53.3 \pm 6.18$ \\
$-\quad$ Liat (Clay) & $\%$ & $18-40$ & $17.0 \pm 11.944$ \\
$-\quad$ Debu (Slit) & $\%$ & $25.10 \pm 3.92$ \\
\hline
\end{tabular}

Keterangan: TPA (kemasaman potensial total), TAA (kemasaman aktual total), TSA (kemasaman sulfida total), SPOS (sulfur aktual)

Description: Total potential acid (TPA), total actual acidity (TAA), total sulphide acid (TSA) and actual sulphur (SPOS) 


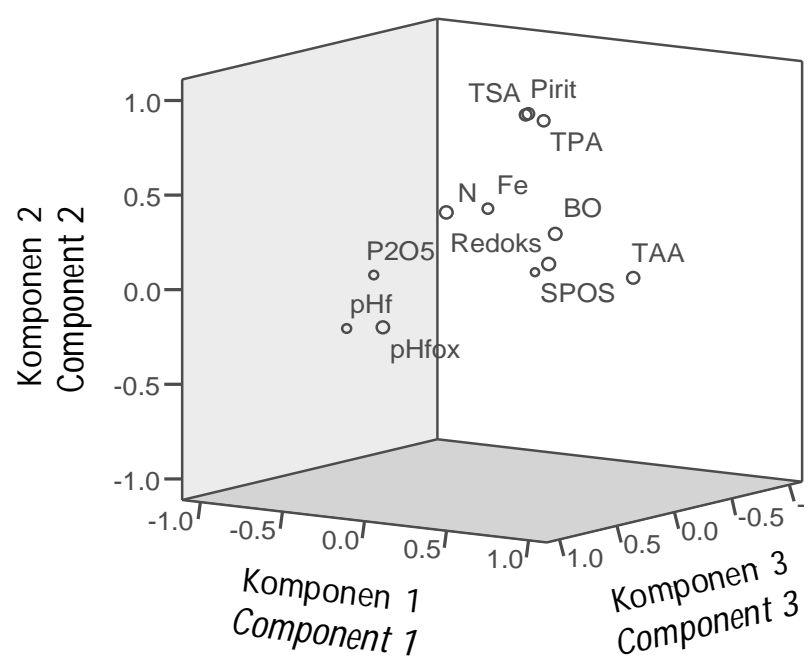

Gambar 2. Analisis komponen utama pada kualitas tanah tambak TSM di Kabupaten Berau, Kalimantan Timur.

Figure 2. Principal component analysis of soil quality of TSM in Berau, East Kalimantan.

bahan organik $(0,678) ; \mathrm{P}_{2} \mathrm{O}_{5}(-0,861)$; dan TAA $(0,941)$. Komponen-2 dengan nilai eigen 1,968; sebesar $16,40 \%$ ditentukan oleh pirit $(0,927)$; TPA $(0,901)$; dan TSA $(0,931)$. Komponen-3 dengan nilai eigen 1,468 sebesar $12,24 \%$ ditentukan oleh $\mathrm{pH}_{\mathrm{Fox}}(0,958)$; $\mathrm{N}(0,759)$; dan $\mathrm{S}_{\text {POS }}(-0,841)$.

Tambak TSM di Kabupaten Berau awalnya terbentuk dari bahan endapan marin yang proses pengendapannya dipengaruhi pasang surut air laut. Pada tambak yang agak ke dalam, pengaruh sungai yang umumnya cukup lebar relatif masih kuat sehingga tanah bagian atas terbentuk dari endapan sungai sedangkan bagian bawah terdapat bahan sulfidik dari pengendapan lumpur yang terjadi sebelumnya.

\section{Kualitas Air}

Kondisi kualitas air berperan bagi keberhasilan budidaya udang windu. Hasil analisis kualitas air tambak disajikan pada Tabel 2. Bahan organik total sangat penting dalam rantai makanan biota perairan.
Bahan organik yang berlebihan dapat menurunkan konsentrasi oksigen dan meningkatkan $\mathrm{CO}_{2}$ dalam air. Perairan termasuk subur bila kandungan bahan organik mencapai $>12,5 \mathrm{mg} / \mathrm{L}$ dan kurang subur bila bahan organik total $<5 \mathrm{mg} / \mathrm{L}$. Pada penelitian ini bahan organik total mencapai kisaran 19,62-44,57 mg/L dan masih dalam batas yang toleran (<30 mg/L). Lokasi tambak berdekatan dengan Sungai Berau yang dipengaruhi secara langsung oleh aktivitas air laut.

Kandungan bahan organik total yang tinggi menunjukkan bahwa banyak serasah atau sisa vegetasi yang masih belum terdekomposisi sempurna. Kondisi ini sering terjadi proses amonifikasi yaitu dekomposisi bahan organik menjadi amonia dan proses nitrifikasi amonia menjadi nitrit dan nitrat. Amonia merupakan hasil utama penguraian protein, namun bila jumlahnya berlebihan akan bersifat racun bagi organisme akuatik. Konsentrasi amonia (total amonia nitrogen) air yang terukur masih dalam batas yang toleran. Menurut Pantjara et al. (2011),

Tabel 2. Kualitas air budidaya udang windu di tambak TSM

Table 2. Water quality of tiger shrimp culture in TSM pond

\begin{tabular}{lccc}
\hline \multicolumn{1}{c}{$\begin{array}{c}\text { Parameter } \\
\text { Parameters }\end{array}$} & $\begin{array}{c}\text { Satuan } \\
\text { Unit }\end{array}$ & $\begin{array}{c}\text { Kisaran } \\
\text { Range }\end{array}$ & $\begin{array}{c}\text { Rata-rata } \\
\text { Average }\end{array}$ \\
\hline BOT & $\mathrm{mg} / \mathrm{L}$ & $19.62-44.57$ & $26.96 \pm 12.77$ \\
Total amonia nitrogen (Total ammonia nitrogen) (TAN) & $\mathrm{mg} / \mathrm{L}$ & $0.07-0.29$ & $0.16 \pm 0.082$ \\
Nitrit (Nitrite) & $\mathrm{mg} / \mathrm{L}$ & $0.01-0.03$ & $0.02 \pm 0.006$ \\
Nitrat (Nitrate) & $\mathrm{mg} / \mathrm{L}$ & $1.12-6.46$ & $3.60 \pm 2.085$ \\
Fosfat (Phosphate) & $\mathrm{mg} / \mathrm{L}$ & $0.01-0.16$ & $0.06 \pm 0.057$ \\
\hline
\end{tabular}


konsentrasi amonia yang tinggi merupakan indikasi adanya pencemaran bahan organik dan limpasan pupuk pertanian. Konsentrasi amonia yang baik di perairan adalah < 1,5 mg/L. Menurut Poernomo (1992), batas konsentrasi amonia yang masih bisa ditolelir untuk kehidupan udang adalah $<1,0 \mathrm{mg} / \mathrm{L}$. Konsentrasi nitrit mencapai kisaran 0,01-0,03 mg/L (rata-rata 0,02 mg/ $\mathrm{L})$, konsentrasi nitrit tergolong rendah dan masih dalam batas yang toleran untuk kehidupan biota akuatik. Menurut Poernomo (1992), batas ambang nitrit untuk budidaya udang di tambak $<0,25 \mathrm{mg} / \mathrm{L}$. Nitrat mencapai kisaran 0,012-6,46 mg/L (rata-rata 3,60 $\mathrm{mg} / \mathrm{L})$. Di perairan, nitrat diperlukan untuk pertumbuhan fitoplankton dan produsen primer lainnya. Dalam air fosfat sebagai ortofosfat yang merupakan senyawa monomer dari $\mathrm{H}_{2} \mathrm{PO}_{4} ; \mathrm{HPO}_{4}^{2-}$, dan $\mathrm{PO}_{4}{ }^{3 \cdot}$. Kandungan fosfat $<0,01 \mathrm{mg} / \mathrm{L}$ akan menghambat pertumbuhan plankton di perairan, karena perairan relatif subur bila konsentrasi fosfat $0,06-20,0 \mathrm{mg} / \mathrm{L}$.

\section{Produksi dan Analisis Ekonomi}

Seperti dijelaskan sebelumnya pada tambak TSM mempunyai tingkat kesuburan yang rendah sehingga dapat menurunkan kualitas air tambak dan memengaruhi pertumbuhan dan produksi udang windu. Pertumbuhan udang windu umur 90 hari mencapai 14-20 g/ekor (rata-rata 16,7 g/ekor). Pada penelitian ini menunjukkan bahwa pengaruh remediasi tambak TSM meningkatkan produktivitas tambak yang lebih baik $357,15 \mathrm{~kg} / \mathrm{ha}$ dibandingkan tanpa remediasi yang menghasilkan udang windu kurang dari $100 \mathrm{~kg} /$ ha (Informasi pembudidaya). Demikian pula dengan informasi pembudidaya lainnya yang umumnya hanya memanen sebanyak 50-100 kg/ha. Pada petak polikultur udang masih stabil dengan rata-rata bobot 12-15 g/ekor (produksi udang windu $250 \mathrm{~kg} / 2,5$ ha atau $100 \mathrm{~kg} / \mathrm{ha}$ ) dan produksi bandeng $825 \mathrm{~kg} / 2,5 \mathrm{ha}$.

Hasil budidaya udang windu dan keuntungan melalui penerapan teknologi remediasi dasar tanah pada budidaya udang windu sistem monokultur dan polikultur berdasarkan analisis ekonomi sederhana disajikan pada Tabel 4.

Pada Tabel 3, untuk budidaya udang windu sistem monokultur diperlukan biaya untuk pembelian benih udang, pakan, pupuk, dan kapur sebesar Rp6.875.000,00. Penerimaan dari penjualan udang pada budidaya udang windu ekstensif Rp32.143.500,00. Penerimaan ini dari penjualan udang sebanyak $357,15 \mathrm{~kg} / \mathrm{ha}$ dengan ukuran udang mencapai 14-20 g/ekor (rata-rata 16,7 g/ekor) dan harga ratarata $\mathrm{Rp} 90.000,00$ per $\mathrm{kg}$; sehingga diperoleh keuntungan sebesar Rp25.268.500,00/ha/siklus dan BC rasio 4,68 (Tabel 4). Pada petak polikultur udang windu yang dibudidaya mencapai bo bot rata-rata $12-15 \mathrm{~g} / \mathrm{ek}$ or (produksi udang windu $100 \mathrm{~kg} / \mathrm{ha}$ ) dan produksi

Tabel 3. Analisis usaha remediasi tambak TSM untuk budidaya udang windu di Kabupaten Berau, Kalimantan Timur (per ha)

Table 3. Economic analysis of remediated TSM ponds for tiger shrimp culture in Berau, East Kalimantan (per ha)

\begin{tabular}{|c|c|c|c|c|}
\hline Ketrangan (Description ) & Volume & $\begin{array}{c}\text { Satuan } \\
\text { Unit }\end{array}$ & $\begin{array}{l}\text { Harga satuan } \\
\text { Unit price (Rp) }\end{array}$ & $\begin{array}{l}\text { Jumlah } \\
\text { Amount (Rp) }\end{array}$ \\
\hline \multicolumn{5}{|c|}{ Biaya operasional (per siklus)/0perational costs (per cycle) } \\
\hline - Benih udang (Shrimp seeds) & 40,000 & ekor & 60 & $2,400,000$ \\
\hline - Pakan udang (Shrimp feed) & 100 & $\mathrm{~kg}$ & 15,000 & $1,500,000$ \\
\hline - Urea (Urea ) & 150 & $\mathrm{~kg}$ & 3,000 & 450,000 \\
\hline - SP 36 & 150 & $\mathrm{~kg}$ & 3,500 & 525,000 \\
\hline - Dolomit & 800 & $\mathrm{~kg}$ & 2,500 & $2,000,000$ \\
\hline \multicolumn{3}{|c|}{ Total biaya (Total cost) } & & $6,875,000$ \\
\hline \multicolumn{5}{|l|}{ Penerimaan (Revenue) } \\
\hline - Produksi udang (shrimp production ) & 357.15 & $\mathrm{~kg}$ & 90,000 & $32,143,500$ \\
\hline \multicolumn{5}{|l|}{ Laba (Profit) } \\
\hline Laba per siklus (Profit per cycle) & & & & $25,268,500$ \\
\hline Laba per tahun (Profit per year) & & & & $50,537,000$ \\
\hline $\mathrm{B} / \mathrm{C}$ rasio $(\mathrm{B} / \mathrm{C}$ ratio $)$ & & & & 4.68 \\
\hline Rentabilitas ekonomi (Economic profit & & & & 367.54 \\
\hline Titik impas (Break-even point) & & & & 19,250 \\
\hline
\end{tabular}


Tabel 4. Analisis usaha remediasi tambak TSM untuk polikultur udang windu dan bandeng di Kabupaten Berau, Kalimantan Timur

Table 4. Economic analysis of remediated TSM pond for polyculture of tiger shrimp and milkfish in Berau, East Kalimantan

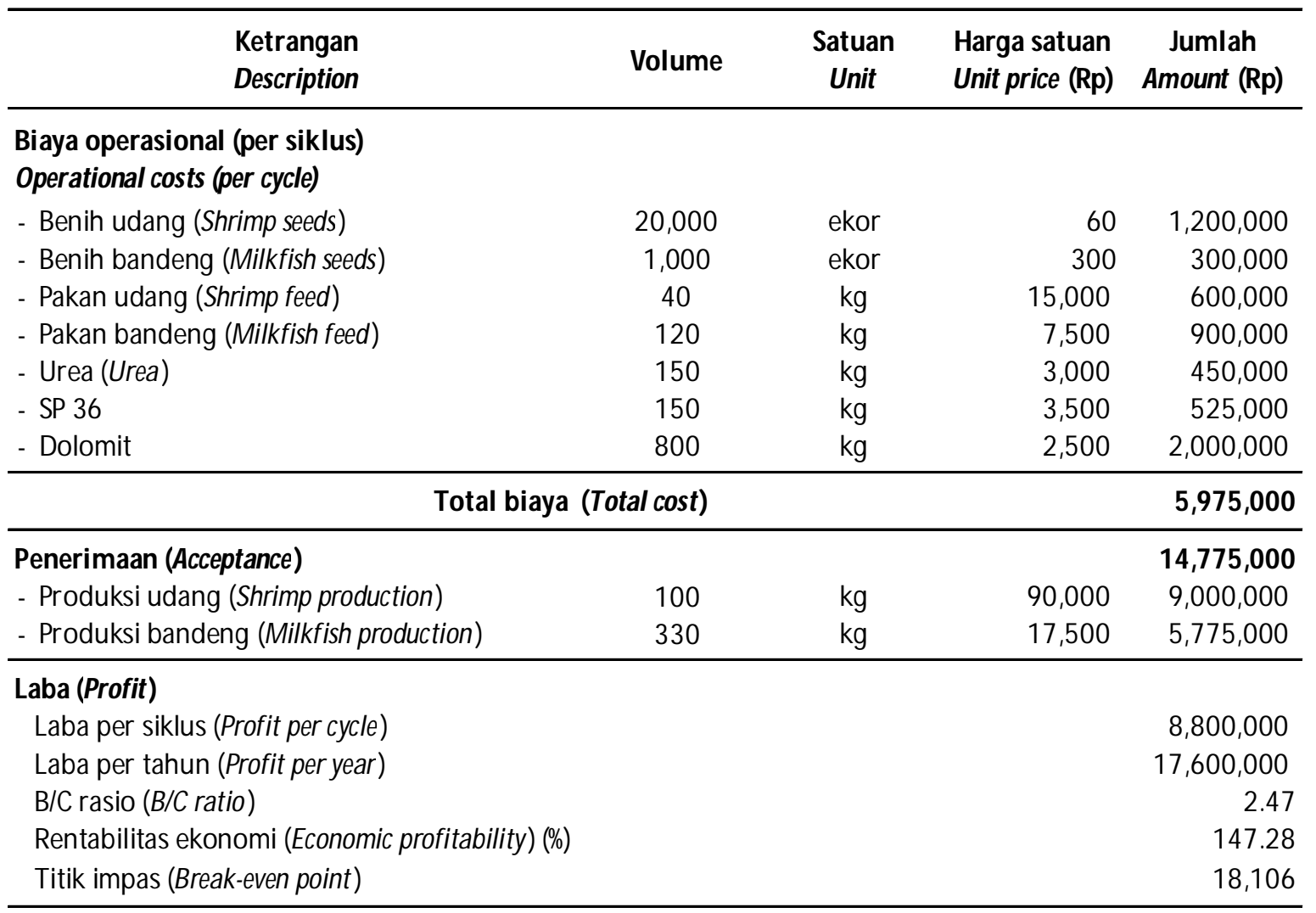

bandeng $330 \mathrm{~kg} / \mathrm{ha}$. Dari hasil tersebut memerlukan biaya untuk pembelian benih udang windu, pakan, pupuk, dan kapur sebesar Rp5.975.000,00. Penerimaan dari penjualan udang pada budidaya udang windu ekstensif Rp32.143.500,00. Penerimaan ini berasal dari penjualan udang windu sebanyak $100 \mathrm{~kg}$ dan bandeng $330 \mathrm{~kg} / \mathrm{ha}$. Harga penjualan udang windu Rp90.000,00/kg dan harga bandeng sebesar Rp17.500,00/kg; sehingga diperoleh keuntungan sebesar Rp8.800.000,00/ha/siklus dan BC rasio 2,47.

Dari hasil analisis usaha sederhana pengaruh remediasi untuk budidaya udang windu di tambak tanah sulfat masam, tampaknya budidaya udang windu sistem monokultur lebih menguntungkan dibandingkan polikultur. Hal ini disebabkan pada saat panen udang windu harga udang windu cukup tinggi (Rp75.000,00-Rp140.000,00/kg) dibandingkan harga bandeng.

\section{KESIMPULAN}

Remediasi tambak TSM menghasilkan udang windu dalam sistem monokultur sebesar $357,15 \mathrm{~kg} / \mathrm{ha}$ dan tanpa remediasi sebesar 50-100 kg/ha, sedangkan untuk polikultur menghasilkan udang windu sebanyak $100,9 \mathrm{~kg} / \mathrm{ha}$ dan bandeng $330 \mathrm{~kg} / \mathrm{ha}$. Penerapan teknologi remediasi dasar tanah pada budidaya udang windu sistem monokultur berdasarkan analisis ekonomi sederhana memberi keuntungan sebesar Rp25.268.500,00/ha/siklus dan BC rasio 4,68 pada polikultur udang windu dan bandeng menghasilkan keuntungan sebesar Rp8.800.000,00/ha/siklus dan BC rasio 2,47 .

\section{UCAPAN TERIMA KASIH}

Ucapan terima kasih disampaikan kepada Pusat Penelitian dan Pengembangan Perikanan Budidaya karena sudah mendanai kegiatan ini melalui APBN 2013. Kepada Balai Penelitian dan Pengembangan Budidaya Air Payau Maros atas fasilitas yang diberikan hingga penelitian ini selesai dilaksanakan.

\section{DAFTAR ACUAN}

Ahern, C.R., Blunden, B., \& Stones, Y. (1998). Acid sulfate soils laboratory methods guidelines. ASSMAC, New South Wales. 
American Public Health Association [APHA]. (1998). Standard methods for examination of water and waste-water. $20^{\text {th }}$ edition. APHA, AWWA, WEF: Washington, 1,085 pp.

Breemen, N.V. (1993). Environmental aspects of acid sulphate soils. In Den, D.K. \& Van Mensvoort, M.E.F. (Eds.). Selected paper of the Ho Chi Minh City Symposium on Acid Sulfat Soils, Vietnam. March 1992, p. 391-402.

Cook, F.J., Hicks, W., Gardner, E.A., Carlin, G.D., \& Froggait, D.W. (2000). Export of acidity in drainage water from acid sulphate soils. Marine Pullution Bulletin, 1(Nos.7-2), 319-326.

Evangelou, V.P. \& Zhang, Y.L. (1995). Pyrite oxidation mechanism and acid mine drainage prevention, Critical Reviews in Environmental Science and Technology, 25(2), 141-199.

Mensvoort, M.E.F.V. \& Dent, D.L. (1998). Acid sulphate soils. In. Lal, R., Blum, W.H., Valintine, C., \& Stewart, B.A. (Eds.). Method for Assesessment of Soil Degradation. Florida: CRC Press LLC, p. 301337.

Pantjara, B. (2004). Pengaruh remediasi tanah sulfat masam dan aplikasi kapur terhadap respons benur windu Penaeus Monodon. Prosiding Konferensi Nasional IV. Balikpapan, 14-17 September 2004. Pengelolaan Sumberdaya Perairan Umum, Pesisir, Pulau-pulau Kecil dan Laut Indonesia. KONAS IVKALTIM, II: 1-18.

Pantjara, B., Nessa, M.N., Monoarfa, W., \& Djawad, I. (2007). Dampak perbaikan pematang tambak tanah sulfat masam terhadap peningkatan produktivitas udang windu. Jurnal Riset Akuakultur, 2(2), 257-269.

Pantjara, B. (2008). Peningkatan produktivitas tambak tanah sulfat melalui reklamasi dan teknik aplikasi dolomit pada skala labotatorium. Prosiding Seminar Nasional Perikanan dan Kelautan. Bidang Budidaya Perairan FPIK-UNBRA dan BPRSE-BRKP, hlm. I-166-I-173.

Pantjara, B., Syah, R., \& Mangampa, M. (2010). Study on tiger prawn (P. monodon) culture in acid sulfate soil ponds, Tarakan, East Kalimantan. Proceeding International Conference of Aquaculture Indonesia (ICAI) and International Conference on Shrimp Culture (ICOSA). Universitas Diponegoro, Semarang. Masyarakat Akuakultur Indonesia, hlm. 1251-1259.

Pantjara, B., Assad, A.I.J., \& Syah, R. (2011). Budidaya tambak ramah mangrove sebagai sarana teaching farm. Dalam Sudradjat, A., Azwar, Z.I., Supriyadi, H., Rachmansyah, Sumiarsa, G.S., Kristanto, A.H., Imron, Parenrengi, A., Insan, I., \& Kusrini, E. (Eds.). Prosiding Forum Inovasi Teknologi Akuakultur. Jilid 1. Jakarta: Pusat Penelitian dan Pengembangan Perikanan Budidaya, hlm. 369-380.

Poernomo, A. (1992). Pemilihan lokasi tambak udang berwawasan lingkungan, Seri Pengembangan Hasil Penelitian No.PHP/Kan/Patek/004/1992, $40 \mathrm{hlm}$.

Ratnawati, E. \& Asaad, A.I.J. (2012). Daya dukung lingkungan tambak di Kecamatan Pulau Derawan dan Sambaliung, Kabupaten Berau Provinsi Kalimantan Timur. Jurnal IImiah Perikanan dan Kelautan, 2(2), 175-185. 